\title{
ЭМБРИОГЕНЕЗ И РЕГЕНЕРАЦИЯ РАСТЕНИЙ В КУЛЬТУРЕ ПЫЛЬНИКОВ ГЕКСАПЛОИДНОЙ ТРИТИКАЛЕ ( Triticosecale Wittmack) ПОД ВЛИЯНИЕМ ЦИТОКИНИНА ЗЕАТИНА
}

\author{
Р.С. ЕРЖЕБАЕВА, М.А. АБДУРАХМАНОВА, Ш.О. БАСТАУБАЕВА, \\ Д. ТАДЖИБАЕВ
}

В селекционных программах зерновых культур обычно используется сочетание методов классической селекции: подбор родительских пар, широкомасштабные скрещивания и гаплоидная технология (культура пыльников и изолированных микроспор), которая позволяет получать гомозиготные линии из гибридов $\mathrm{F}_{1}$. Для селекции пшеницы и тритикале широко применяются методы андрогенеза (культура пыльников и изолированных микроспор). В настоящее время основная проблема андрогенеза тритикале заключается в низкой эффективности получения зеленых растений. В наших экспериментах по культуре пыльников тритикале впервые использован цитокинин зеатин как экзогенный фитогормон индукционной среды. Установлена его оптимальная концентрация, улучшен процесс формирования эмбриоидов и регенерация зеленых растений. Целью выполненного исследования было улучшение технологии культуры пыльников тритикале и изучение эффекта от добавления цитокинина зеатина в питательную среду для индукции эмбриогенеза и регенерации зеленых растений. В экспериментах были использованы линии ярового тритикале (ЯТХ-327-11 и Зернокормовое 5 - двуручка) и две линии озимого тритикале (Т-968 и Т-45). Донорные растения для гаплоидной технологии выращивали в условиях научного полевого стационара (орошаемый) ТОО Казахский НИИ земледелия и растениеводства (Казахстан, Алматинская обл.). На срезанные колосья воздействовали низкими температурами (4 ${ }^{\circ} \mathrm{C}$ в течение 14 сут), после изоляции пыльников их подвергли высокотемпературной обработке (при $32{ }^{\circ} \mathrm{C}$ в течение 3 сут). Стерилизацию колосьев проводили 0,1\% раствором дихлорида ртути. В качестве базовой питательной среды для индукции эмбриогенеза использовали модифицированную среду mW14. Сравнили пять вариантов с различными концентрациями зеатина («Sigma-Aldrich», Индия) в питательной среде $(0,2 ; 0,4 ; 0,6 ; 0,8$ и 1,0 мг/л), контролем служила среда без добавления зеатина. Пыльники выделяли из колоса в асептических условиях и помещали в пластиковые чашки Петри (100 пыльников на одну чашку с 6 мл жидкой питательной среды для индукции эмбриогенеза). В каждом варианте использовали 500 пыльников. Пыльники инкубировали в темноте при $32{ }^{\circ} \mathrm{C}$ в течение первых 3 сут, затем в термостате с температурой $25-28{ }^{\circ} \mathrm{C}$ до появления новообразований. Андрогенные структуры (АС), достигшие в длину 2,0-2,5 мм, пересаживали на питательную среду для регенерации. Их инкубировали при 16-часовом фотопериоде, освещении 10 тыс. лк и температуре 24-26 ${ }^{\circ}$ С. Адаптацию растений-регенерантов к почве осуществляли в климатической камере KBWF 720 («Binder GmbH», Германия). Для растений-регенерантов озимого тритикале проводили яровизацию в холодильной камере в течение 6 нед при 3-4 ${ }^{\circ} \mathrm{C}$ и непрерывном освещении. Введение в питательную среду зеатина в концентрациях 0,2-0,8 мг/л приводило к увеличению формирования АС на 42,3-65,2 \%. Наибольшее влияние на выход андрогенных структур зафиксировано при добавлении 0,4 мг/л зеатина: образовалось в среднем 112 АС/100 пыльников при значении в контрольном варианте 67,8 АС/100 пыльников. В питательной среде для индукции эмбриогенеза, где концентрация зеатина составляла 0,4-0,6 мг/л наблюдалось формирование большего количества эмбриоидов (на 16,9-24,1 \% по сравнению с контролем, $\mathbf{p} \leq \mathbf{0 , 0 0 0 1 )}$, имеющих биполярную структуру и дающих при регенерации побег и корни, что показывает положительное влияние зеатина на дифференцировку и органогенез делящихся клеток микроспор. Зафиксировано достоверное увеличение формирования зеленых растений во всех вариантах опыта по сравнению с контролем. Самую высокую частоту регенерации зеленых растений (6,3 шт/100 пыльников) отмечали у эмбриодов, которые были пересажены с питательной среды, содержащей зеатин в концентрации 0,6 мг/л. Добавление зеатина и влияние генотипа оказались статистически значимыми факторами при образовании андрогенных структур и регенерации. Эффективность спонтанного удвоения набора хромосом у тритикале составила 26,5 \%, что позволило без болезненного этапа колхицинирования получить 97 дигаплоидных линий из перспективных линий тритикале.

Ключевые слова: тритикале, культура пыльников, зеатин, эмбриоид, регенерация, альбиносные растения, зеленые растения, спонтанное удвоение.

\footnotetext{
* Работа выполнена в рамках финансирования Комитета науки МОН РК по бюджетной программе 217 «Развитие науки», подпрограмме 102 «Грантовое финансирование научных исследований», проект ИРН № AP05132430.

934
} 
Тритикале (× Triticosecale Wittmack) - вид, созданный посредством скрещивания пшеницы (Triticum spp.) и ржи (Secale cereale L.). Сочетание аллелей обоих предшественников позволяет растениям адаптироваться к среде, которая менее благоприятна для пшеницы, но обеспечивает лучший выход биомассы и качество корма. Тритикале обладает значительным потенциалом для производства зерна и кормов, хотя исследования по улучшению урожайности этого вида отстают от аналогичных работ по другим зерновым культурам. Он также приобретает популярность как покровная культура для улучшения состояния почвы и уменьшения вымывания питательных веществ. Тритикале, как и рожь, подходит и для линейных, и для гибридных методов селекции. Достижения в области молекулярной биологии и богатство генетических ресурсов пшеницы и ржи могут быть использованы для улучшения тритикале (1).

Площадь под зерновыми колосовыми культурами в Казахстане составила в 2018 году 14209,3 тыс. га (2). Для Казахстана актуально возделывание яровых и озимых форм тритикале, но соответствующие селекционные программы только развиваются. В селекции зерновых культур обычно используется сочетание методов классической селекции: подбор родительских пар, широкомасштабные скрещивания и гаплоидная технология (культура пыльников и изолированных микроспор), которая позволяет получать гомозиготные линии из гибридов $\mathrm{F}_{1}$. Эффективность основных методов культуры пыльников и изолированных микроспор тритикале зависит от таких факторов, как генотип, условия выращивания, время сбора донорных растений, использование предварительной обработки (холод, тепло, углеводное голодание), состав питательной среды для индукции эмбриогенеза и регенерации растений. Большинство успехов в изучении культуры пыльников тритикале было достигнуто благодаря развитию гаплоидной технологии у пшеницы (3).

В настоящее время достаточно высокие показатели получены при использовании двух методов андрогенеза (4-7). Культура изолированных микроспор эффективнее по сравнению с культурой пыльников, однако этот метод более трудоемкий, требующий тонких манипуляций при разделении микроспор в градиенте плотности, что может вызвать затруднения при работе с большим количеством гибридных комбинаций.

Регуляторы роста - один из важных факторов в андрогенезе. Индукцией эмбриогенеза можно манипулировать, используя различные типы и концентрации экзогенных фитогормонов, а также сроки их присутствия в питательной среде (8). В культуру пыльников и изолированных микроспор зерновых культур ауксины вводят для инициации деления микроспор. Добавление 2,4-дихлорфеноксиуксусной кислоты $(2,4-Д)$ позволило достигнуть высоких результатов при получении андрогенных структур и зеленых растений (9). Применение ауксина 2,4-Д описано во многих успешных протоколах $(4,10,11)$. В качестве регуляторов роста, действующих в комбинации с акусином, чаще всего используют 6-бензиламинопурин (БАП) и кинетин (12-14). Однако в некоторых работах, где применялся зеатин, были достигнуты достаточно высокие результаты по частоте образования эмбриоидов (53-68 \%) и формированию зеленых растений (20-22 шт/100 пыльников) $(15,16)$.

Зеатин - растительный гормон класса цитокининов, выделенный из незрелых зерновок кукурузы. В культуральных средах для растений это широко используемая альтернатива кинетину, 6-бензиламинопурину или изопентенил-аденозину (17). Зеатин участвует в дифференцировки каллусной ткани in vitro и органогенезе (18-21), успешно применяется для экс- 
периментального андрогенеза перца и баклажана $(22,23)$.

Несмотря на эффективные протоколы и постоянную оптимизацию питательных сред, условий культивирования и предобработки, учет других факторов, увеличивающих выход дигаплоидных линий, проблемой остается воспроизводимость результатов, низкий выход зеленых растений и зависимость результата от генотипа. Для широкомасштабного использования и производства удвоенных гаплоидов тритикале необходима оптимизация уже существующих отработанных протоколов.

В наших экспериментах по культуре пыльников тритикале впервые использован цитокинин зеатин как экзогенный фитогормон индукционной среды. Установлена его оптимальная концентрация, улучшен процесс формирования эмбриоидов и регенерация зеленых растений.

Целью настоящего исследования было улучшение эффективности технологии культуры пыльников тритикале и изучение эффекта от добавления цитокинина зеатина в питательную среду для индукции эмбриогенеза и регенерации зеленых растений.

Методика. В эксперименте использовали тритикале яровых (ЯТХ327-11 и Зернокормовое 5) и озимых (Т-968 и Т-45) сортов и линий, отзывчивых на индукцию эмбриогенеза и регенерации в культуре пыльников $(24,25)$.

Донорные растения для гаплоидной технологии выращивали в 2017 году (орошаемый полевой стационар, ТОО Казахский НИИ земледелия и растениеводства - ТОО «КазНИИЗиР», Республика Казахстан, Алматинская обл., Карасайский р-н). Незрелые соцветия отбирали с донорных растений в фазу флагового листа, не вышедшего из листового влагалища, с микроспорами, находящимися на средней и поздней одноядерной стадиях развития. Стадию развития микроспор оценивали по общепринятой методике (световая микроскопия временных давленых препаратов) (26).

Все срезанные донорные растения выдерживали в холодильной установке при температуре $4{ }^{\circ} \mathrm{C}$ в течение 14 сут (27). Колосья, прошедшие холодовую обработку, стерилизовали $0,1 \%$ раствором дихлорида ртути (сулема) в течение 6 мин на шейкере, а затем трижды по 3 мин промывали стерильной дистиллированной водой.

В качестве базовой среды для индукции эмбриогенеза при изучении влияния фитогормона зеатина использовали модифицированную среду mW14 (28) с добавлением 90 г/л мальтозы («ТМ Media», Индия), 1000 мг глутамина-L («AppliChem GmbH », Германия) (12), 2 мг/л синтетического ауксина 2,4-Д («Aldrich Chemistry», США), 50 г/л фиколла 400 («Sigma Life Science», Швеция). Для снятия ингибирования эмбриогенеза фенольными соединениями, выделяемыми из отмирающих пыльников, в питательную среду добавляли аскорбиновую кислоту (4 мг/л) (24). Варианты опыта различались по концентрации зеатина («Sigma-Aldrich», Индия) в питательной среде (I, II, III, IV, V - соответственно 0,2;0,4;0,6;0,8 и 1,0 мг/л), контролем служила среда без добавления зеатина.

Пыльники выделяли из колоса в асептических условиях и помещали в пластиковые чашки Петри диаметром 60 мм (100 пыльников на одну чашку с 6 мл жидкой питательной среды для индукции эмбриогенеза) (29). В каждом варианте использовали по 500 пыльников. В питательную среду добавляли антибиотик (цефатоксим) в концентрации 200 мг/л для предотвращения контаминации. Пыльники инкубировали в темноте при $32{ }^{\circ} \mathrm{C}$ в течение первых 3 сут, а затем переносили в термостат с температурой 25$28{ }^{\circ} \mathrm{C}$ до появления новообразований.

В процессе выделения и после переноса в культуральную среду за 
состоянием микроспор наблюдали на микроскопе серии МТ4000 («Meiji Tеchno», Япония; увеличение $\times 40-\times 1000)$.

Андрогенные структуры (АС), достигшие размера 2,0-2,5 мм, пересаживали на питательную среду для регенерации в чашки Петри диаметром 90 мм (20-30 андрогенных структур на чашку). Более мелкие АC оставляли в среде для дальнейшего роста. После каждого такого переноса в среду добавляли 1 мл свежей аналогичной среды.

Материал, пересаженный на питательную среду для регенерации растений, инкубировали при 16-часовом фотопериоде, освещении 10 тыс. лк и температуре $24-26{ }^{\circ} \mathrm{C}$. Для регенерации использовали готовую смесь компонентов питательной среды Мурасиге и Скуга (MC) («Sigma Life Science», США) с добавлением 2 мг/л зеатина («Sigma-Aldrich», Индия), 30 г/л сахарозы («AppliChem GmbH», Германия) и 6 г/л агара («B\&V srl», Италия). Для корнеобразования применяли готовую смесь компонентов питательной среды МС с добавлением 0,5 г/л гидролизата казеина («Fluka Analytical», США), 20 г/л сахарозы, 2 мг/л индолилмасляной кислоты-3 (ИМК) («Sigma Life Science», Китай), 6 г/л агара.

Плоидность полученных растений определяли на анализаторе Су Flow Ploidy Analyser («Sysmex Partek GmbH», Германия). Пробы для анализа подготавливали с использованием набора CyStain ${ }^{\circledR}$ UV Precise P («Sysmex Partek GmbH», Германия).

Адаптацию растений-регенерантов к почве проводили в климатической камере KBWF 720 («Binder GmbH», Германия), где поддерживалась температура 23-24 ${ }^{\circ} \mathrm{C}$, освещенность 8-10 тыс. лк и влажности $80 \%$. В течение первых 2 нед (период адаптации) растения-регенеранты опрыскивали раствором фитогормонов (кинетин - 0,5 мг/л, гибберелловая кислота 2 мг/л, никотинамид - 3 мг/л). Растения-регенеранты озимых линий тритикале подвергали яровизации в холодильной камере в течение 6 нед при 3-4 ${ }^{\circ} \mathrm{C}$ и непрерывном освещении.

Статистическую обработку выполняли на языке программирования $\mathrm{R}$ с открытым исходным кодом - R version 3.2 .3 (2015-12-10) (Wooden Christmas-Tree) (https://www.r-project.org/alt-home/). Рассчитывали средние $(M)$ и стандартные отклонения $( \pm \mathrm{SD})$. Выполняли стандартные параметрические тесты с использованием встроенных библиотек и дополнительных пакетов (dplyr, gglot, pisch и др.): регрессионный анализ, определение статистической достоверности (Analysis of Variance, ANOVA) и попарное сравнение средних значений по критерию Тьюки.

Результаты. Наблюдения за развитием микроспор и образованием андрогенных структур вели в течение всего периода культивирования пыльников. Выход микроспор из пыльцевого мешка в жидкую питательную среду происходил очень быстро и составил 70-80 \%. Появление первых андрогенных структур отмечали через 18-25 сут с начала культивирования в зависимости от генотипа тритикале. Большая часть андрогенных структур формировалась из отдельных микроспор при прямом эмбриогенезе и обладала всеми структурами, типичными для нормального эмбриона. У генотипа ЯТХ-327-11 зафиксировали образование АС уже в середине 3-й нед культивирования во всех вариантах опыта. У трех других образцов видимые АС начали появляться на 4-й нед культивирования.

В контроле образовывалось в среднем 67,8 АC на 100 пыльников по всем образцам, в опыте - 96,5-112 АС на 100 пыльников (табл. 1). Наибольший выход андрогенных структур наблюдали во II варианте опыта (концентрация зеатина 0,4 мг/л), где образовалось в среднем 112 АС на 100 пыльников. На некоторых чашках Петри формировалось до 300 АС. 
Полученные результаты оказались на порядок выше значений, которые были получены в культуре пыльников другими авторами, - более 50 эмбриоподобных структур на 100 пыльников на средах СНB-3 и NPB99 (30), 5,8-20,7 эмбриоподобных структур на 100 пыльников на средах 190-РАА и 190-D/K (13) и 47,2-55,5 эмбриоподобных структур на 100 пыльников на среде mW14 (4). Однако отметим, что в некоторых исследованиях с использованием культуры изолированных микроспор у отзывчивых модельных генотипов наблюдалась достаточно высокая степень формирования андрогенных структур - до 500 эмбриоподобных структур на 100 пыльников $(4,7)$.

1. Результаты эмбриогенеза и регенерации растений у яровых и озимых линий тритикале (× Triticosecale Wittmack) при добавлении в индукционную среду разных концентраций зеатина $(M \pm \mathrm{SD})$

\begin{tabular}{|c|c|c|c|c|c|c|}
\hline \multirow{2}{*}{ Генотип } & \multicolumn{6}{|c|}{ Вариант опыта } \\
\hline & контроль & I & II & III & IV & V \\
\hline \multicolumn{7}{|c|}{ Образов ание а нд рогенны с структур, шт/100 пыльников } \\
\hline \multicolumn{7}{|c|}{ Яровые линии: } \\
\hline ЯТХ-327-11 & $74,0 \pm 15,2$ & $143,0 \pm 8,4$ & $160,0 \pm 15,8$ & $122,0 \pm 41,4$ & $126,0 \pm 25,1$ & $76,0 \pm 35,0$ \\
\hline Зернокормовое 5 (сорт) & $50,0 \pm 15,8$ & $55,0 \pm 12,2$ & $60,0 \pm 15,8$ & $56,0 \pm 23,0$ & $54,0 \pm 18,2$ & $46,0 \pm 20,7$ \\
\hline \multicolumn{7}{|l|}{ Озимые линии: } \\
\hline $\mathrm{T}-968$ & $64,0 \pm 16,7$ & $93,0 \pm 8,3$ & $98,0 \pm 11,4$ & $98,0 \pm 19,2$ & $100,0 \pm 11,4$ & $110,0 \pm 29,1$ \\
\hline $\mathrm{T}-45$ & $83,0 \pm 12,0$ & $108,0 \pm 14,8$ & $130,0 \pm 15,8$ & $110,0 \pm 23,8$ & $110,0 \pm 16,4$ & $84,0 \pm 35,1$ \\
\hline$M \pm \mathrm{SD}$ & $67,8 \pm 12,2$ & $99,8 \pm 31,5$ & $112,0 \pm 37,6$ & $96,5 \pm 24,8$ & $97,5 \pm 26,7$ & $79,0 \pm 22,8$ \\
\hline \multirow{2}{*}{\multicolumn{7}{|c|}{ Реге е н рация з е ле ных р ас те н и й, шт/100 пыльников }} \\
\hline & & & & & & \\
\hline ЯТХ-327-11 & $1,4 \pm 1,4$ & $2,2 \pm 0,8$ & $2,6 \pm 1,9$ & $3,6 \pm 2,1$ & $2,4 \pm 1,3$ & $2,8 \pm 1,1$ \\
\hline Зернокормовое 5 (сорт) & $2,2 \pm 0,8$ & $4,4 \pm 1,5$ & $7,0 \pm 1,6$ & $7,8 \pm 2,2$ & $7,4 \pm 1,5$ & $8,6 \pm 2,9$ \\
\hline \multicolumn{7}{|l|}{ Озимые линии: } \\
\hline $\mathrm{T}-968$ & $2,2 \pm 0,8$ & $4,0 \pm 0,7$ & $5,4 \pm 1,1$ & $7,0 \pm 1,0$ & $4,4 \pm 7,7$ & $5,8 \pm 2,1$ \\
\hline $\mathrm{T}-45$ & $2,6 \pm 1,1$ & $4,2 \pm 1,4$ & $6,4 \pm 2,1$ & $6,8 \pm 0,4$ & $5,0 \pm 2,3$ & $5,8 \pm 2,1$ \\
\hline \multirow[t]{2}{*}{$M \pm \mathrm{SD}$} & $2,1 \pm 0,4$ & $3,7 \pm 0,9$ & $5,4 \pm 1,7$ & $6,3 \pm 1,6$ & $4,8 \pm 1,7$ & $5,7 \pm 2,1$ \\
\hline & ация ал & ь б и н о с н ь & I $\mathrm{X}$ p a c $\mathrm{Te} \mathrm{H}$ & и й, шт/100 & ыльников & \\
\hline \multicolumn{7}{|l|}{ Яровые линии: } \\
\hline ЯТХ-327-11 & $33,4 \pm 13,0$ & $50,2 \pm 7,5$ & $25,8 \pm 14,1$ & $18,6 \pm 6,1$ & $33,4 \pm 4,7$ & $28,8 \pm 8,3$ \\
\hline Зернокормовое 5 (сорт) & $34,6 \pm 7,5$ & $26,8 \pm 2,9$ & $23,6 \pm 4,0$ & $28,2 \pm 4,9$ & $24,4 \pm 3,7$ & $21,0 \pm 3,8$ \\
\hline \multicolumn{7}{|l|}{ Озимые линии: } \\
\hline $\mathrm{T}-968$ & $34,2 \pm 4,0$ & $26,7 \pm 2,9$ & $22,3 \pm 4,0$ & $29,0 \pm 6,5$ & $23,8 \pm 7,4$ & $20,4 \pm 5,0$ \\
\hline $\mathrm{T}-45$ & $31,6 \pm 7,7$ & $26,9 \pm 2,9$ & $32,2 \pm 13,9$ & $26,0 \pm 8,1$ & $21,0 \pm 5,6$ & $19,4 \pm 4,8$ \\
\hline$M \pm \mathrm{SD}$ & $33,4 \pm 1,2$ & $32,6 \pm 10,1$ & $25,9 \pm 3,80$ & $25,4 \pm 4,1$ & $25,6 \pm 4,7$ & $22,4 \pm 3,7$ \\
\hline При м е ч ан и е. Опис & вариантов & см. в разделе & «Методика». & & & \\
\hline
\end{tabular}

Для выявления зависимости эмбриогенеза от генотипа и добавления фитогормона зеатина был проведен дисперсионный анализ (табл. 2). Зеатин и генотип оказались статистически значимыми факторами при образовании андрогенных структур и регенерации.

2. Статистический анализ (ANOVA) влияния генотипа и присутствия зеатина в индукционной среде на эмбриогенез и регенерацию растений у изученных яровых и озимых линий тритикале (× Triticosecale Wittmack)

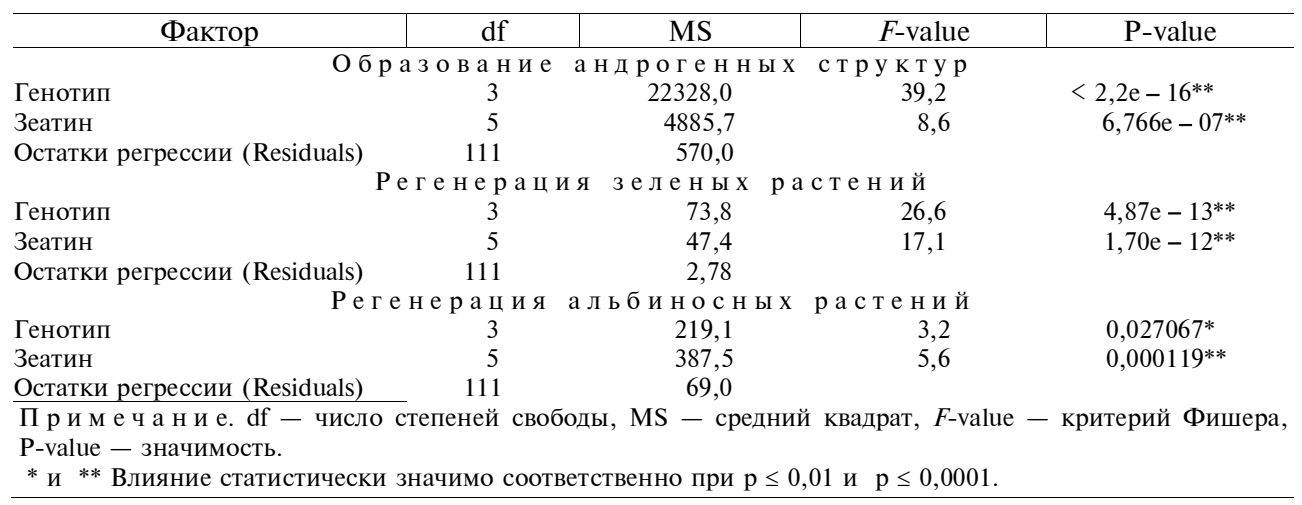


После обнаружения существенной разницы между группами в целом мы применили регрессионный анализ для установления количественной взаимосвязи между показателями и факторами (зеатин, генотип). Для образования андрогенных структур наиболее высокий коэффициент $\beta$-регрессии - 43,3 отмечали во II варианте с концентрацией зеатина 0,4 мг/л (табл. 3). Генотипы показали неодинаковую отзывчивость на андрогенную технологию (см. табл. 3): наибольшие регрессионные $\beta$-коэффициенты были характерны для ЯТХ-327-11 и Т-45 - соответственно 63,3 и 50,0.

3. Регрессионный анализ влияния генотипа и присутствия зеатина в индукционной среде на эмбриогенез и регенерацию зеленых растений у изученных яровых и озимых линий тритикале (× Triticosecale Wittmack)

\begin{tabular}{|c|c|c|}
\hline \multirow{2}{*}{ Параметр } & \multicolumn{2}{|c|}{$\beta$-Коэффициент множественной регрессии } \\
\hline & \multicolumn{2}{|c|}{ образование андрогенных структур регенерация зеленых растений } \\
\hline & \multicolumn{2}{|c|}{ Концент р ация з е атин а, мг/л } \\
\hline 0,0 (Intercept) & $29,4 * * *$ & $3,6^{* * *}$ \\
\hline 0,2 & $32,0 * * *$ & $1,6^{* *}$ \\
\hline 0,4 & $43,3^{* * *}$ & $3,2 * * *$ \\
\hline 0,6 & $28,3^{* *}$ & $4,2^{* * *}$ \\
\hline 0,8 & $29,5^{* *}$ & $2,7 * * *$ \\
\hline 1,0 & 11,2 & $3,7 * * *$ \\
\hline & Ге н о ти п & \\
\hline Сорт Зернокормовое 5 (Intercept) & $29,4^{* * *}$ & $3,6 * * *$ \\
\hline ЯТХ-327-11 & $63,3^{* * *}$ & $-3,7 * * *$ \\
\hline $\mathrm{T}-968$ & $39,8^{* * *}$ & $-1,4^{* *}$ \\
\hline $\mathrm{T}-45$ & $50,0^{* * *}$ & $-1,1^{*}$ \\
\hline
\end{tabular}

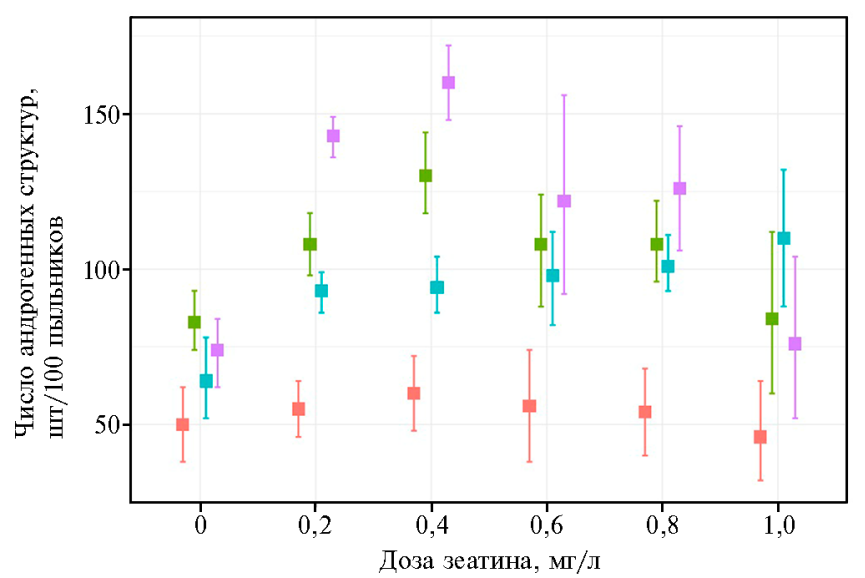

Рис. 1. Образование андрогенных структур у яровых и озимых линий тритикале (× Triticosecale Wittmack) при разных концентрациях зеатина в индукционной среде и в зависимости от генотипа: - сорт Зернокормовое $5, \square-$ T-45, — - T-968, - ЯТX-327-11.
Применение критерия Тьюки для попарного сравнения среднего числа образовавшихся андрогенных структур при разных концентрациях зеатина и в контрольном варианте показало наличие статистически значимой разницы $\left(\mathrm{p}_{\mathrm{adj}}<0,01\right)$ для концентраций 0,2-0,8 мг/л. Наибольшую разность между групповыми средними отмечали между контролем и II вариантом 43,2 (результаты статистической обработки по критерию Тьюки). В це-

лом полученные результаты согласуются с визуальной оценкой различий, которая представлена на диаграмме размахов (рис. 1).

Андрогенные структуры, достигшие размера 2,0-2,5 мм, пересаживали на питательную среду для регенерации (рис. 2, Г). Регенерация растений происходила в течение 3-14 сут после пассажа. У генотипов ЯТХ327-11 и Т-968 регенерацию растений частично наблюдали в среде для индукции эмбриогенеза в темноте. Из андрогенных структур, пересаженных в контрольном варианте, регенерировало в среднем по разным генотипам 2,1 зеленых растений на 100 пыльников. Наибольшую частоту регенерации зеленых растений (6,3 шт/100 пыльников) отмечали в III варианте. Мак- 
симальную частоту регенерации зеленых растений зафиксировали у генотипа Зернокормовое 5 (8,6 шт/100 пыльников) (см. табл. 1). Результаты наших исследований сопоставимы с данными, полученными в исследованиях F. Eudes с соавт. (30) и S. Tuvesson с соавт. (31) (6 и более зеленых растений на 100 пыльников). Большие значения (10,8-16,8 зеленых растений на 100 пыльников) получены венгерскими учеными $(4,13)$.

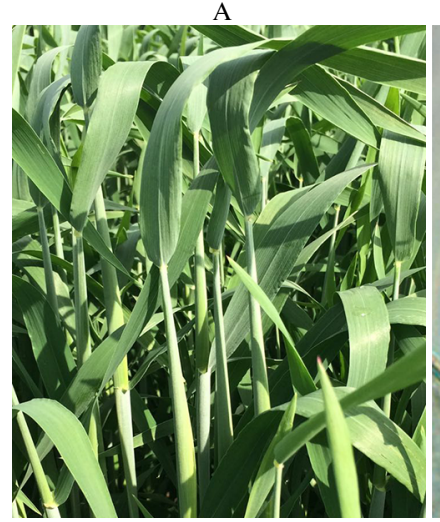

$\Gamma$
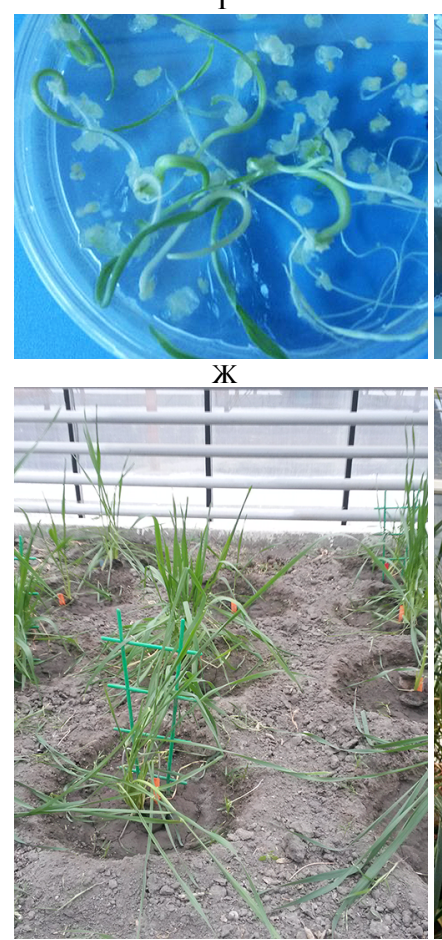

Б

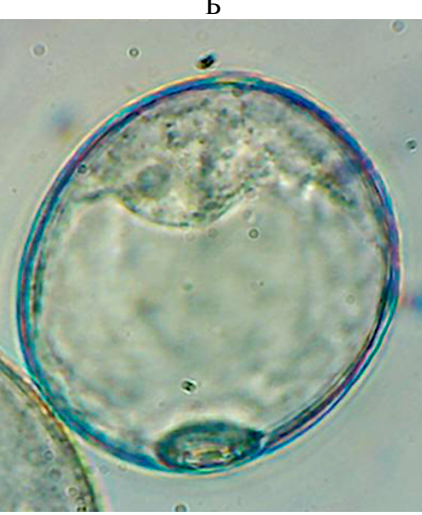

Д
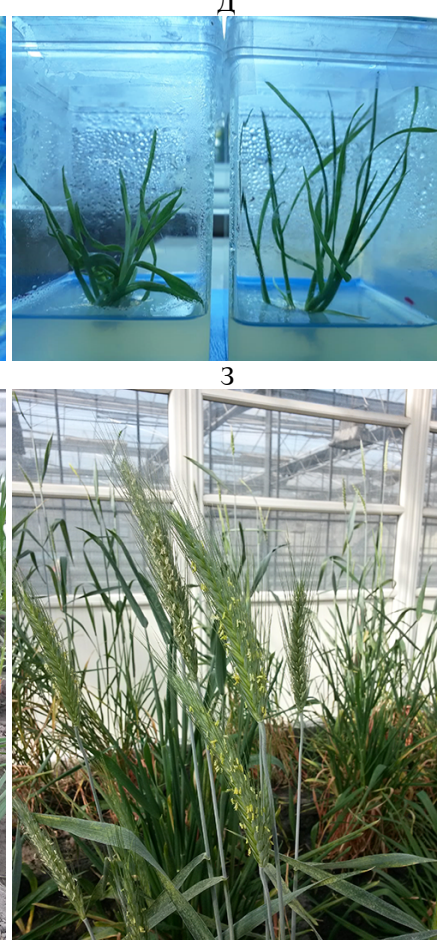

B

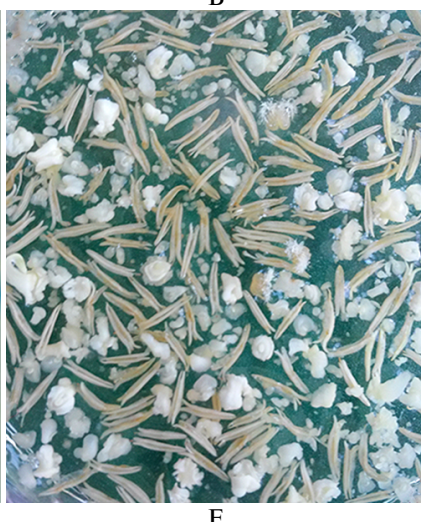

$\mathrm{E}$

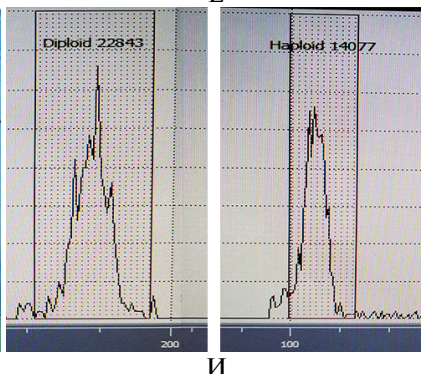

И

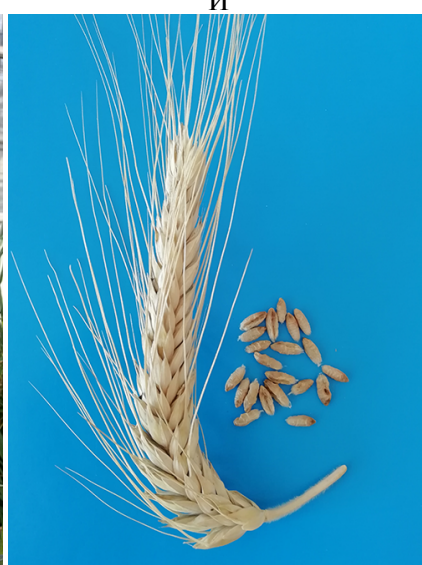

Рис. 2. Основные этапы получения регенерантов в культуры пыльников тритикале (х Triticosecale Wittmack): А - донорные колосья сорта Зернокормовое 5 в поле; Б - микроспора линии ЯТХ-327-11 на поздней одноядерной стадии (увеличение $\times 1000$, микроскоп МТ4000, «Meiji Тechno», Япония); В - андрогенные структуры линии Т-968 в среде для индукции эмбриогенеза, II вариант опыта; Г - регенерация растения линии Т-45 из эмбриоидов, III вариант опыта; Д - зеленые растения линии Т-45 на питательной среде для укоренения, II вариант опыта; Е - результаты анализа плоидности на приборе Су Flow Ploidy Analyser («Sysmex Partek GmbH», Германия); Ж - дигаплоидные растения линии T-968, II вариант опыта в теплице; 3 - цветение дигаплоидных растений линии Т-968, III вариант опыта; И колосья с семенами фертильных дигаплоидных растений линии Т-968, II вариант опыта. Описание вариантов опыта см. в разделе «Методика».

Проведенный регрессионный анализ показал положительное влия- 
ние увеличения концентрации зеатина на регенерацию зеленых растений (см. табл. 3). Наибольший коэффициент регрессии $(\beta=4,2)$ получили в III варианте (см. табл. 3). Наличие статистически значимой разницы $\left(\mathrm{p}_{\mathrm{adj}}<0,05\right)$ между опытом и контролем отмечали при всех концентрациях зеатина. При этом наибольшую разность также зафиксировали между контролем и III вариантом опыта $-4,2$.

Регенерация альбиносных (лишенных хлорофилла) проростков в контрольном варианте в среднем по линиям составила 33,4 шт/100 пыльников. При увеличении концентрации зеатина наблюдалось снижение числа альбиносных проростков, и их наименьшее число отмечали в V варианте опыта (22,4 шт/100 пыльников).

Гаплоидные растений могут быть получены из изолированных пыльников посредством прямой регенерации соматических зародышей (эмбриоидогенез) и через каллусогенез. Эффективность формирования эмбриоидов зависит от генотипа и может существенно различаться, варьируя от 0 до $95 \%$ (32). Лишь некоторые исследователи уделяют внимание дифференцировке образовавшихся андрогенных структур на каллусы и эмбриоиды (30).

4. Образование эмбриоидов, зеленых растений и дигаплоидных линий у изученных яровых и озимых форм тритикале (× Triticosecale Wittmack) в зависимости от конщентрации зеатина в индукционной среде

\begin{tabular}{|c|c|c|c|c|c|c|c|}
\hline \multirow[b]{2}{*}{ Вариант } & \multirow{2}{*}{$\begin{array}{l}\text { Пересажен- } \\
\text { ные андро- } \\
\text { генные } \\
\text { структуры }\end{array}$} & \multirow[b]{2}{*}{$\begin{array}{l}\text { Эмбриои- } \\
\text { ды, всего } \\
(\%)\end{array}$} & \multirow[b]{2}{*}{$\begin{array}{l}\text { Каллусы, } \\
\text { всего (\%) }\end{array}$} & \multirow[b]{2}{*}{$\begin{array}{l}\text { Зеленые } \\
\text { растения }\end{array}$} & \multicolumn{2}{|c|}{ Растения, всего (\%) } & \multirow{2}{*}{$\begin{array}{l}\text { Спонтанно } \\
\text { удвоенные дига- } \\
\text { плоидные линии, } \\
\text { всего (\%) }\end{array}$} \\
\hline & & & & & $\begin{array}{l}\text { пересажен- } \\
\text { ные в грунт }\end{array}$ & $\begin{array}{l}\text { акклимати- } \\
\text { зированные } \\
\text { к грунту }\end{array}$ & \\
\hline & 949 & & & 45 & & & $7(24,1)$ \\
\hline I & 13 & & & & & & \\
\hline II & 1 & 1040 & 514 & 110 & 87 & 68 & 2 \\
\hline III & 13 & $, 0)^{* *}$ & 396 & 114 & $95(83,3)$ & 86 & ,9) \\
\hline IV & 13 & $4,0)^{* *}$ & $6,0)$ & 93 & $68(73,1)$ & $60(88,2)$ & $3,3)$ \\
\hline V & 1185 & $720(60,8)^{* * *}$ & $465(39,2)$ & $117^{* *}$ & $89(76,1)$ & $81(91,0)$ & $19(23,4)$ \\
\hline Всего & 7795 & $4793(61,0)$ & $3002(39,0)$ & 558 & $423(75,8)$ & $366(86,5)$ & $97(26,5)$ \\
\hline
\end{tabular}

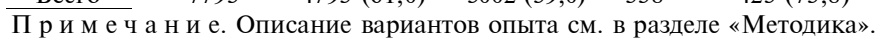

* и ** Влияние статистически значимо соответственно при $\mathrm{p} \leq 0,001$ и $\mathrm{p} \leq 0,0001$ (ANOVA); нз - влияние статистически не значимо.

A

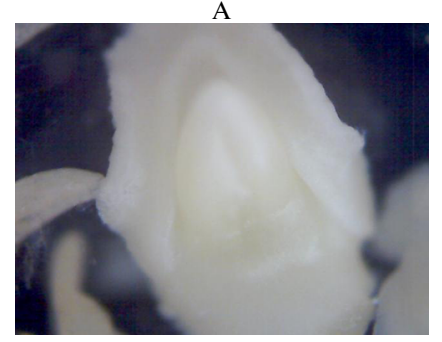

Б

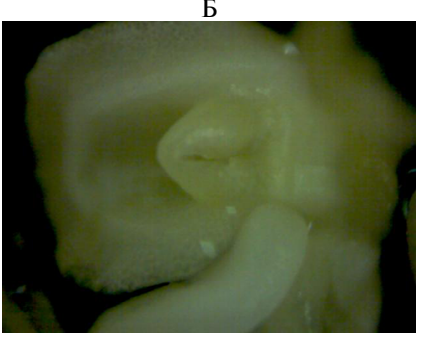

B

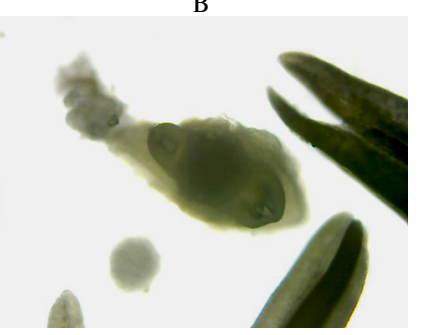

Рис. 3. Эмбриоиды тритикале (х Triticosecale Wittmack), полученные в культуре пыльников: А линия Т-45, II вариант опыта; Б - линия ЯТХ-327-11, II вариант опыта; В - линия ЯТХ327-11, III вариант опыта (увеличение ×40, микроскоп МТ4000, «Meiji Теchnо», Япония). Описание вариантов опыта см. в разделе «Методика».

При пересадке на агаризованную среду для регенерации все андрогенные структуры в нашем опыте были дифференцированы на эмбриоиды (рис. 3), имеющие биполярную структуру, и каллусы. С контрольной среды, не содержащей зеатина, было пересажено 949 АС, из которых 57,2 \% представляли собой эмбриоиды (табл. 4). Во всех вариантах, где в среде присутствовал цитокинин, отмечали более высокий процент формирования эмбриоидов $(60,8-71,0 \%)$, за исключением I варианта $(45,0 \%)$. Максимальная доля эмбриоидов образовалась в III варианте $(71,0 \%)$. Регене- 
рация растений из эмбриоидов происходила в $92 \%$ случаев, при этом формировались как побег, так и корни.

Для адаптации к грунту отобрали зеленые растения, которые имели хорошо сформированную корневую систему и листья. У $24 \%$ растений отмечали отсутствие корня, слабое развитие, курчавость листьев ввиду недостаточного формирования механической ткани. В течение первых 2 нед после пересадки (период адаптации) растения-регенеранты опрыскивали раствором фитогормонов и поливали водным раствором солей макро-, микроэлементов, хелата железа по прописи МС. Акклиматизацию к почве проводили в климатической камере при высокой влажности (80\%). Адаптацию к грунту прошли 366 растений, что составляло 86,5 \% (см. табл. 4).

Конечным результатом описанной технологии культуры пыльников тритикале становится получение дигаплоидных растений. В отработанных протоколах осуществляют воздействие на микроспоры высокими и низкими температурами, способствующими спонтанному удвоению хромосом на ранних стадиях культивирования. Спонтанное удвоение позволяет исключить процесс колхицинирования, который тяжело переносят растения-регенеранты. В нашем опыте спонтанное удвоение было зафиксировано у $26,5 \%$ из 366 растений-регенерантов. Это средний показатель для тритикале, который согласуется с данными других исследователей $(4,7,9)$ (в некоторых работах он достигал 57 \%) (33). Гаплоидные растения, у которых не произошла спонтанная дигаплоидизация, после достаточного укоренения и развития на стадии кущения были подвергнуты колхицинированию. Все полученные дигаплоидные растения были доведены до семян в тепличных условиях (см. рис. 2, 3, И).

Таким образом, введение фитогормона зеатина в концентрациях 0,2-0,8 мг/л в жидкую питательную среду mW14 для индукции эмбриогенеза у яровых и озимых форм тритикале приводило к увеличению формирования андрогенных структур (АС) на 42,3-65,2 \%. Наибольшее влияние на выход андрогенных структур оказывало добавление 0,4 мг/л зеатина (образование в среднем 112 АС на 100 пыльников). В питательной среде, где концентрация зеатина составляла 0,4-0,6 мг/л, была установлена более высокая по сравнению с контролем частота формирования эмбриоидов (на 16,9-24,1 \%), имеющих биполярную структуру и дающих при органогенезе побег и корни. То есть зеатин в индукционной среде улучшал дифференцировку делящихся клеток микроспор и органогенез и способствовал формированию эмбриоидов. Мы также зафиксировали достоверное увеличение формирования зеленых растений во всех вариантах опыта (3,76,3 шт/100 пыльников) по сравнению с контролем (2,1 шт/100 пыльников). Самая высокая частота регенерации зеленых растений (6,3 шт/100 пыльников была отмечена у эмбриодов, пересаженных с питательной среды, содержащей зеатин в концентрации 0,6 мг/л. Эффективность спонтанной дигаплоидизации у тритикале составила 26,5 \%, что позволило без болезненного этапа колхицинирования получить 97 дигаплоидных линий тритикале.

Авторы выражают благодарность сотрудникам Центра цифровых технологий ТОО «КазНИИЗиР» (Казахстан), выполнивщих статистическую обработку полученных данных.

\section{ЛИТЕРАТУРА}

1. Ayalew H., Kumssa T.T, Butler T.J., Ma X.F. Triticale improvement for forage and cover crop uses in the southern great plains of the United States. Front. Plant Sci., 2018, 9: 1130 (doi: 
10.3389/fpls.2018.01130).

2. Официальная статистическая информация. Посевные площади сельскохозяйственных культур под урожай 2018 года в Республике Казахстан. Режим доступа: http://stat.gov.kz/official/industry/14/statistic/7. Дата обращения: 22.09.2018.

3. Eudes F., Chugh A. An overview of triticale doubled haploids. In: Advances in haploid production in higher plants /A. Touraev, B.P. Forster, S.M. Jain (eds.). Springer, Dordrecht, 2009: 8796 (doi: 10.1007/978-1-4020-8854-4_6).

4. Lantos C., Bóna L., Boda K., Pauk J. Comparative analysis of in vitro anther- and isolated microspore culture in hexaploid triticale $(\times$ Triticosecale Wittmack $)$ for androgenic parameters. Euphytica, 2014, 197(1): 27-37 (doi: 10.1007/s10681-013-1031-y).

5. Würschum T., Tucker M.R., Maurer H.P. Stress treatments influence efficiency of microspore embryogenesis and green plant regeneration in hexaploid triticale $(\times$ Triticosecale Wittmack L.). In Vitro Cell. Dev. Biol. - Plant, 2014, 50(1): 143-148 (doi: 10.1007/s11627-013-9539-3).

6. Würschum T., Tucker M.R., Maurer H.P., Leiser W. Ethylene inhibitors improve efficiency of microspore embryogenesis in hexaploid triticale. Plant Cell Tiss. Organ. Cult., 2015, 122(3): 751-757 (doi: 10.1007/s11240-015-0808-1).

7. Oleszczuk S., Sowa S., Zimny J. Direct embryogenesis and green plant regeneration from isolated microspores of hexaploid triticale ( $\times$ Triticosecale Wittmack) cv. Bogo. Plant Cell Rep., 2004, 22(12): 885-893 (doi: 10.1007/s00299-004-0796-9).

8. Zheng M.Y., Konzak C.F. Effect of 2,4-dichlorophenoxyacetic acid on callus induction and plant regeneration in anther culture of wheat (Triticum aestivum L.). Plant Cell Rep., 1999, 19(1): 69-73 (doi: 10.1007/s002990050712).

9. Hassawi D.S., Qi J., Liang G.H. Effects of growth regulator and genotype on production of wheat and triticale polyhaploids from anther culture. Plant Breeding, 1990, 104(1): 40-45 (doi: 10.1111/j.1439-0523.1990.tb00400.x).

10. Ponitka A., Ślusarkiewicz-Jarzina A. The effect of liquid and solid medium on production of winter triticale ( $\times$ Triticosecale Wittm.) anther-derived embryos and plants. Cereal Research Communications, 2007, 35(1): 15-22 (doi: 10.1556/CRC.35.2007.1.3).

11. González J.M., Jouve N. Microspore development during in vitro androgenesis in triticale. Biologia Plantarum, 2005, 49(1): 23-28 (doi: 10.1007/s10535-005-3028-4).

12. Lantos C., Páricsi S., Zofajova A., Weyen J., Pauk J. Isolated microspore culture of wheat (Triticum aestivum L.) with Hungarian cultivars. Acta Biologica Szegediensis, 2006, 50(1-2): 31-35.

13. Pauk J., Puolimatka M., Tóth K.L., Monostori T. In vitro androgenesis of triticale in isolated microspore culture. Plant Cell Tiss. Organ. Cult., 2000, 61: 221-229 (doi: 10.1023/A:1006416116366).

14. Broughton S. Ovary co-culture improves embryo and green plant production in anther culture of Australian spring wheat (Triticum aestivum L.). Plant Cell Tiss. Organ. Cult., 2008, 95(2): 185-195 (doi: 10.1007/s11240-008-9432-7).

15. Kim K.M., Baenziger P.S. A simple wheat haploid and doubled haploid production system using anther culture. In Vitro Cell. Dev. Biol. - Plant, 2005, 41(1): 22-27 (doi: 10.1079/IVP2004594).

16. Тураев А., Мишуткина Я.В., Нескородов Я.Б., Скрябин К.Г. Способ получения дигаплоидных растений ячменя из культивируемых микроспор in vitro. Патент 2557389 (РФ) МКИ C12N15/82, А01H4/00, А01Н1/04. ФГБОУ ВО «Московский государственный университет им. М.В. Ломоносова» (РФ) № 2013144618/10. Заявл. 04.10.2013. Опубл. 10.04.2015. Бюл. № 10.

17. Zeatin (6[4-hydroxy-3-methyl-cis-2-butenylamino]purine). In: Encyclopedia of genetics, genomics, proteomics and informatics. Springer, Dordrecht, 2008 (doi: 10.1007/978-1-4020-6754-9_18377).

18. Seldimirova O.A., Kudoyarova G.R., Kruglova N.N., Zaytsev D.Y., Veselov S.Y. Changes in distribution of zeatin and indole-3-acetic acid in cells during callus induction and organogenesis in vitro in immature embryo culture of wheat. In Vitro Cell. Dev. Biol. - Plant, 2016, 52(3): 251-264 (doi: 10.1007/s11627-016-9767-4).

19. Shri P.V., Davis T.M. Zeatin-induced shoot regeneration from immature chickpea (Cicer arietinum L.) cotyledons. Plant Cell Tiss. Organ. Cult., 1992, 28(1): 45-51 (doi: 10.1007/BF00039914).

20. Kumar R., Mamrutha H.M., Kaur A., Venkatesh K., Grewal A., Kumar R. Development of an efficient and reproducible regeneration system in wheat (Triticum aestivum L.). Physiol. Mol. Biol. Plants, 2017, 23(4): 945-954 (doi: 10.1007/s12298-017-0463-6).

21. Santa-Maria M., Pecota K.V., Yencho C.G., Allen G., Sosinski B. Rapid shoot regeneration in industrial 'high starch' sweetpotato (Ipomoea batatas L.) genotypes. Plant Cell Tiss. Organ. Cult., 2009, 97(1): 109-117 (doi: 10.1007/s11240-009-9504-3).

22. Hegde V., Partap P.S., Yadav R.C., Baswana K.S. In vitro androgenesis in Capsicum (Capsicum annuum L.). Int. J. Curr. Microbiol. App. Sci., 2017, 6(5): 925-933 (doi: 10.20546/ijcmas.2017.605.102).

23. Dehkehan M.E., Moieni A., Movahedi Z. Effects of zeatin riboside, mannitol and heat stress on eggplantn (Solanum melongena L.) anther culture. Iranian journal of Genetics and Plant Breeding, 2017, 6(1): 16-26.

24. Yerzhebayeva R.S., Abekova A.M., Ainebekova B.A., Urazaliyev K.R., Bazylova T.A., Daniyarova A.K., Bersimbayeva G.Kh. Influence of different concentrations of ascorbic and gibberellic 
acids and $\mathrm{pH}$ of medium on embryogenesis and regeneration in anther culture of spring triticale. Cytology and Genetics, 2017, 51(6): 448-454 (doi: 10.3103/S0095452717060032).

25. Ержебаева Р.С., Берсимбаева Г.Х., Азирбаева А.Т. Скрининг образцов тритикале в культуре пыльников in vitro. Mam. IV Межд. конф. «Генофонд и селекция растений». Новосибирск, 2018: 110-115.

26. Паушева З.П. Практикум по цитологии растений. М., 1988.

27. Lantos C., Pauk J. Anther culture as an effective tool in winter wheat (Triticum aestivum L.) breeding. Russian Journal of Genetics, 2016, 52(8): 794-801 (doi: 10.1134/S102279541608007X).

28. Jia X., Zhuang J., Hu S., Ye C., Nie D. Establishment and application of the medium of anther culture of intergeneric hybridsof Triticum aestivum $\times$ Triticum-Agropyron. Sci. Agri. Sinica, 1994, 27: 83-87.

29. Rubtsova M., Gnad H., Melzer M., Weyen J., Gils M. The auxins centrophenoxine and 2,4-D differ in their effects on non-directly induced chromosome doubling in anther culture of wheat (T. aestivum L.). Plant Biotechnol. Rep., 2012, 7(3): 247-255 (doi: 10.1007/s11816-012-0256-x).

30. Eudes F., Amundsen E. Isolated microspore culture of Canadian 6 triticale cultivars. Plant Cell Tiss. Organ. Cult., 2005, 82(3): 233-241 (doi: 10.1007/s11240-005-0867-9).

31. Tuvesson S., Ljungberg A., Johanson N., Karlsson K.-E., Suijs W., Josset J.-P. Large-scale production of wheat and triticale doubled haploids through the use of a single-anther culture method. Plant Breeding, 2000, 119(6): 455-459 (doi: 10.1046/j.1439-0523.2000.00536.x).

32. Germanà M.A. Anther culture for haploid and doubled haploid production. Plant Cell Tiss. Organ. Cult., 2011, 104(3): 283-300 (doi: 10.1007/s11240-010-9852-z).

33. Ślusarkiewicz-Jarzina A., Ponitka A. Efficient production of spontaneous and induced doubled haploid triticale plants derived from anther culture. Cereal Research Communications, 2003, 31: 289-296.

ТОО Казахский НИИ земледелия и растениеводства, 040909 Казахстан, Алматинская обл., Карасайский р-н, п. Алмалыбак, ул. Ерлепесова, 1,

e-mail: raushan_2008@mail.ru $₫$, abduraxmanova58@inbox.ru,

sh.bastaubaeva@mail.ru,daniyar.taj@gmail.com
Поступила в редакцию

16 августа 2019 года

Sel'skokhozyaistvennaya biologiya [Agricultural Biology], 2019, V. 54, № 5, pp. 934-945

\section{EFFECT OF ZEATIN ON in vitro EMBRYOGENESIS AND PLANT REGENERATION FROM ANTHER CULTURE OF HEXAPLOID TRITICALE $(\times$ Triticosecale Wittmack)}

\section{R.S. Yerzhebayeva, M.A. Abdurakhmanova, Sh.O. Bastaubayeva, D. Tadjibayev}

LLP Kazakh Research Institute of Agriculture and Plant Growing, 1, Erlepesov str., Almalybak v., Karasay District, Almaty Region, 040909 Republic of Kazakhstan, e-mail raushan_2008@mail.ru ( $\triangle$ corresponding author), abduraxmanova58@inbox.ru, sh.bastaubaeva@mail.ru, daniyar.taj@gmail.com

ORCID:

Yerzhebayeva R.S. orcid.org/0000-0003-4585-8505

Bastaubayeva Sh.O. orcid.org/0000-0003-2588-5880

Abdurakhmanova M.A. orcid.org/0000-0002-1337-0647 Tadjibayev D. orcid.org/0000-0002-5956-2644

The authors declare no conflict of interests

Acknowledgements:

The authors are grateful to the employees of the Center for Digital Technologies (KazNIIZiR LLP) for the data statistical processing.

Supported financially by Science Committee of the Ministry of Education and Science of the Republic of Kazakhstan under budget program 217 "Development of science", subprogram 102 "Grant funding for research", IRN project No. AP05132430

Received August 16, 2019

doi: 10.15389/agrobiology.2019.5.934eng

\section{Abstract}

To achieve results sooner, cereal crop selection programs usually combine conventional methods, such as selection of parents and large-scale cross-breeding with haploid technology, a methodology which allows obtaining homozygous lines from the $F_{1}$ hybrids. Methods of androgenesis (anther culture and isolated microspore culture techniques) have gained widespread use for selection of wheat and triticale. Currently, the main issue for the androgenesis in Triticale is the low efficiency of green plant regeneration. The present work, for the first time ever, utilizes cytokinin zeatin as an exogenic phytohormone in the induction medium, and determines its concentration optimal for improving embryo formation and green plant regeneration from the triticale anther culture. The aim of this research is to increase efficiency of the triticale anther culture, and study the effects of adding cytokinin zeatin to the nutrient medium on embryogenesis induction and regeneration. Two lines of spring triticale, YaTKh-327-11 and Zernokormovoye 5 (facultative), and two lines of winter triticale, 
T-968 and T-45, were used. Donor plants for the haploid technology were grown in the irrigated field of Kazakh Research Institute of Agriculture and Plant Growing LLP (Kazakhstan, Almaty Region). Cut spikes were subjected to low temperature $\left(4{ }^{\circ} \mathrm{C}\right.$ for 14 days), and then the anthers, after they were isolated, to high temperature $\left(32{ }^{\circ} \mathrm{C}\right.$ for 3 days). The spikes were sterilized with $0.1 \%$ solution of mercuric chloride. Modified mW14 medium was used as the basic nutrient medium for embryogenesis induction. Five variants of nutrient medium were studied, with concentration of phytohormone zeatin gradually increasing in each subsequent variant $(0.2 \mathrm{mg} / 1,0.4 \mathrm{mg} / \mathrm{l}, 0.6 \mathrm{mg} / \mathrm{l}$, $0.8 \mathrm{mg} / \mathrm{l}, 1.0 \mathrm{mg} / \mathrm{l}$ ), and medium without zeatin served as control. The study conducted on 4 genotypes of triticale has shown that addition of zeatin to the nutrient mediums in concentrations of $0.2-$ $0.8 \mathrm{mg} / \mathrm{l}$ increased the rate of androgenic structure formation by 42.3-65.2\%. Maximal effect on the androgenic structure formation was achieved at $0.4 \mathrm{mg} / 1$ concentration of zeatin, with 112 androgenic structures (AS) per 100 anthers on average compared to 67.8 AS per 100 anthers in control group. In the embryogenesis inducing nutrient mediums with $0.4-0.6 \mathrm{mg} / \mathrm{l}$ zeatin concentrations the rate of embryogenesis was 16.9-24.1\% higher compared to the control, with embryos having bipolar structure, and producing stem and roots during the regeneration, which indicates positive effect of zeatin on differentiation and organogenesis of the dividing microspore cells. All the variants in the experiment showed a significant increase in the rate of regeneration compared to the control with no zeatin added. In embryos transplanted from the medium containing $0.6 \mathrm{mg} / \mathrm{l}$ zeatin the rate of green plant regeneration was the highest reaching $6.3 \mathrm{pcs} / 100$ anthers. It has been established that addition of zeatin and the effect of genotype were the statistically significant factors for androgenic structure formation and regeneration. Efficiency of spontaneous chromosome doubling in triticale amounted to $26.5 \%$, which has allowed producing 97 double haploid lines from the promising lines of triticale without colchicination.

Keywords: triticale, anther culture, zeatin, embryo, regeneration, albino plants, green plants, spontaneous doubling.

\section{Научные собрания \\ $8^{\text {th }}$ INTERNATIONAL CONGRESS \& EXPO ON BIOTECHNOLOGY AND BIO-ENGINEERING} (June 22-23, 2020, Toronto, Canada)

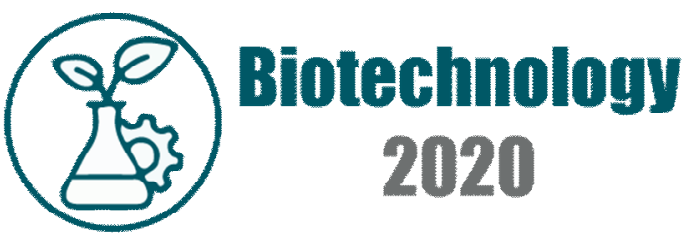

We cordially invite all the participants who are interested in sharing their knowledge and research in the area of Biotechnology \& Bio-engineering.

Biotechnology-2020 expects more than 300 participants around the globe with fascinating plenary sessions, keynote sessions, Oral Presentations and Poster Presentations. The attending delegates include 100 International Members of related International journals. this is an excellent proposal for the delegates from universities and institutes to interact with the world class scientists.

This will bring together world leaders in their respective fields in the fascinating environment of Toronto, Canada. Biotechnology-2020 Conference is to explore on current issues of progression of technologies and novel advances in biotechnology \& bio-engineering.

The desire of the Biotechnology-2020 is to assist the advantage of quality research and real-world impact in an atmosphere of true international cooperation between scientists by bringing the purpose of world class researchers, International Communities and Industrial heads to discuss the latest developments and innovations in the fields of Biotechnology and Bio-engineering with colleagues from different countries and other parts of Canada.

\section{Conference Objectives:}

- To facilitate circumstances for networking, collaboration and exchange of ideas with internationally eminent leaders in Biotechnology \& Bio-engineering- 2020 .

- To identify research and practice based innovations in optimizing Biotechnology \& Bioengineering research and development.

- To debate gaps and priorities for sustainable development in optimizing Biotechnology \& Bio-engineering research and development.

- To discuss and discourse the challenges and opportunities in the new era of optimizing Biotechnology \& Bio-engineering research and development reforms.

- To identify opportunities for evidence-based practice in optimizing Biotechnology \& Bioengineering research and development.

Information: https://www.scientificfederation.com/biotechnology-2020/ 